\title{
Place of residence and age as variables differentiating health behaviours and perception of health by women past menopause
}

\author{
Anna B. Pilewska-Kozak ${ }^{1, A-F}{ }^{\oplus}$, Beata Dobrowolska2,E-F ${ }^{2}$, Grażyna Stadnicka, ${ }^{3, B}$, \\ Bartłomiej Drop ${ }^{4, C}{ }^{\oplus}$, Marian Jędrych ${ }^{4, C} \oplus$ \\ ${ }^{1}$ Chair and Department of Gynaecology and Gynaecological Endocrinology, Faculty of Health Sciences, Medical \\ University, Lublin, Poland \\ ${ }^{2}$ Department of Development in Nursing, Faculty of Health Sciences, Medical University, Lublin, Poland \\ ${ }^{3}$ Department of the Basics of Midwifery, Faculty of Health Sciences, Medical University, Lublin, Poland \\ ${ }^{4}$ Department of Informatics and Medical Statistics, Faculty of Health Sciences, Medical University, Lublin, Poland \\ A - Research concept and design, B - Collection and/or assembly of data, C - Data analysis and interpretation, \\ $D$ - Writing the article, E - Critical revision of the article, F- Final approval of article.
}

Pilewska-Kozak AB, Dobrowolska B, Stadnicka G, Drop B, Jędrych M. Place of residence and age as variables differentiating health behaviours and perception of health by women past menopause. Ann Agric Environ Med. 2019; 26(1): 165-173. doi: 10.26444/aaem/102496

\begin{abstract}
Introduction. Research on the meaning of health and health behaviors is important for the development of health education programmes which should be tailored to the needs of patients.

Objective. The aim of the study is to determine whether the place of residence and age have an impact on health behaviours and the perception of health by women past menopause.

Materials and method. A survey method and three research instruments were employed: authors' questionnaire, the Health Behaviour Inventory and the Health Criteria List by Juczyński, and the Kupperman Index. The study was carried out among a sample of 102 women after menopause hospitalised in a hospital in eastern Poland.

Results. The overall health behaviour indicator $(\mathrm{HBI})$ in the study group was found to reach an average value of $80.1 \pm 12.7$ points. A higher $\mathrm{HBI}$ indicator was found to be characteristic of urban rather than rural residents; however, there was no statistically significant difference $(p>0.05)$. The age of respondents did not differentiate statistically their health behaviours ( $p>0.05)$. Women who reported their last menstruation before the age of 50 obtained higher results in the dimension of health practices (HPs) than those whose last menstruation ceased after the age of $50(p<0.05)$. The respondents attributed the highest importance to health, understood as a property, a state and a goal. Statistically significant differences were observed in the importance of the statement according to which health is a process of "being able to work without tension and stress", as the respondents from urban areas assigned to it a higher average weight than those from rural areas $(p<0.05)$.

Conclusions. A higher overall HBI, as well as indicators for particular categories, were characteristic of women from urban areas. Age did not significantly differentiate the women's health behaviours. Rural residents were dominant in the group of women who rated their health to be very good or good. The respondents attributed the highest importance to health understood as a property, state and goal.
\end{abstract}

Key words

health behaviours, perception of health, women pastmenopause, place of residence

\section{INTRODUCTION}

The postmenopausal period begins 12 months after the woman has had her last menstruation. Some authors are of the opinion that this period lasts until the end of life [1]. It is characterised by many complex biological transformations as well as changes of a psychosocial nature. Problems in both private and professional life start to appear, and along with health behaviours impact on the woman's condition [2]. In order to maintain proper wellbeing and health during this period, it is important for a woman to modify her lifestyle

Address for correspondence: Anna B. Pilewska-Kozak Chair and Department of Gynaecology and Gynaecological Endocrinology, Faculty of Health Sciences, Medical University, Lublin, Poland

e-mail: apilewska@poczta.wp.pl

Received: 04.10.2018; accepted: 03.01.2019; first published: 16.01.2019 by incorporating health-oriented measures and eliminating behaviours that exert a destructive effect on health. Healthoriented behaviours are aimed at fostering prevention, as well as help the restoration and maintenance of good health in the physical, mental and social spheres [3]. The adoption of healthy behaviours may significantly improve a woman's health condition and mitigate the intensity with which she experiences the symptoms of the menopause syndrome $[4,5,6]$.

By pursuing appropriate health behaviours, the woman builds a kind of general picture of her attitudes towards health and, therefore, of herself as a person $[3,7,8]$. The understanding of health with regard to daily life may deviate from the generally adopted scientific concepts and be different depending on the person. The overall self-assessment of health is a constituent in one's own "self", and the varied 
terminology of this concept results from determinants of a psychosocial nature (age, gender, place of residence, system of values, etc.). However, for most people "being healthy" primarily means not experiencing any symptoms of disease and the ability to perform their social roles $[9,10$, 11]. Health, regardless of differences in interpretation of the definition, is considered to be an axiological category which, by determining many aspects of human life, may take on an autotelic character or constitute an indirect value necessary to achieve other life goals $[12,13]$. Consequently, the position occupied by health in the hierarchy of human values governs the sense of responsibility for one's own health and the choice of behaviours aimed at achieving it. The safe fulfilment of health potential, however, is the ability to optimally position it in relation to other life values $[14,15,16,17]$.

\section{OBJECTIVE}

The aim of the study is to determine whether the place of residence and age have an impact on health behaviours and the perception of health by women past menopause.

\section{MATERIALS AND METHOD}

The study was carried out in the Gynaecological Oncology and Gynaecology Ward of the Independent Public Clinical Hospital No. 1 in Lublin, eastern Poland, using a diagnostic survey method.

A convenience sampling method was used. The study involved 118 postmenopausal women aged 40-82 (56 \pm 7.8 years), 102 of whom qualified for statistical analysis. The inclusion criteria for a woman to be included in the study group were:

- a minimum of one year past her last ever menstruation (menopause);

- lack of documented chronic illnesses presented at the medical interview;

- giving consent to participate in the study.

The authors utilised four research instruments:

1. own survey questionnaire, which was made of two parts. The first part comprised a personal information section with questions on the subject of the study - sociodemographic data. The second part featured open and closed questions aimed to provide information on the analysed area;

2. the Health Behaviour Inventory (Polish: Inwentarz Zachowań Zdrowotnych, IZZ). The Health Behaviour Inventory devised by Juczyński [18], addressed to both healthy and ill adults. It includes 24 statements which describe various kinds of health-related behaviours (eating habits, preventive behaviours, positive mental attitude, health practices) displayed by respondents during the 12-month period preceding the study. Proper eating habits (PEH) include, first of all, the types of food consumed (whole wheat bread, vegetables and fruit, etc.). The statements describing preventive behaviours (PB) concern issues such as the following of health recommendations and obtaining information on health and diseases. On the other hand, health practices (HPs) include everyday habits regarding sleep and rest or physical activity. Positive mental attitude (PMA) is understood as the avoidance of strong emotions, stress, tension, and depressing situations. Health behaviours determined by the Health Behaviour Inventory include three main types of behaviours [18]:

- behaviours which are known to decrease or increase the risk of disease;

- behaviours pursued out of conviction that they contribute to the maintenance of health or a reduction in the risk of disease;

- behaviours connected with following medical recommendations.

Juczyński used the results of health promoting programmes to choose statements most conducive to the assessment of health behaviours. Additionally, he applied several tools for the purpose of examining health practices the General Preventive Health Behaviour Checklist and Reported Health Behaviour Checklist [18]. However, their parametric values turned out to be insufficient, as a number of statements in these tools did not meet the functional equivalence criterion resulting from Polish socio-economic conditions. At that point, Juczyński decided to devise his own questionnaire, using statements which matched the Polish cultural conditions.

The respondents were asked to mark the frequency with which they performed health-related activities listed in the questionnaire by rating them on a 5-point scale: 1 almost never; 2 - rarely; 3 - from time to time; 4 - often; 5 - almost always. The average time to complete the survey was limited to 5 minutes. The numerical values marked by the respondents were counted to determine intensification of the overall health behaviour indicator. The value was a score from 24-120 points. The higher the indicator, the higher the increase in health behaviours. The overall indicator was then converted into standardised values - "sten". The results varied within the range of 1-4 sten (low), 5-6 sten (average), 7-10 sten (high). Intensification of the 4 categories of health behaviours was calculated separately - the average number of scores in each category constituted the indicator according to a standardised key, i.e. the sum of scores divided by 6 .

3. The Health Criteria List (Polish: Lista Kryteriów Zdrowia, LKZ) by Juczyński [18]. This refers to a holistic approach to health and includes 24 statements describing the positive elements of various aspects of physical, mental and social health. The statements are assigned to different categories, defining health as: state, target, process, property or result. Having read and marked those criteria which a respondent considers most significant in terms of health, he or she chooses 5 criteria in order of importance, arranging them from the most ( 5 points) to the least important (1 point). The study takes an average time of 10 minutes and can be carried out individually or in groups. In group studies, health criteria that were not selected should be assigned « $0 »$ points. The questionnaire allows results to be obtained from each category, as well as the hierarchy of the 5 most important values which the examined individual associated with health. As a result, a ranks order was obtained from all possible 24 health criteria. In addition, it is worth paying attention to the distribution of rank numbers for individual health criteria.

4. Additionally, in order to evaluate the intensification of postmenopausal symptoms, the Kupperman Index was applied, [19] developed in 1959 and includes an evaluation 
of 11 symptoms. The following elements are assessed: hot flashes, increased sweating, sleep disorders, nervousness, depressed mood, dizziness, general weakness, painful joints and headaches, palpitation, paresthesias. The presence of each symptom is scored (multiplier from $0-3$ points), depending on the severity of the symptom (none, slight, medium, severe). Next, the score set by Kupperman and assigned to the given symptom is multiplied by the multiplier. After summing up, the final result reflects the severity of climacteric symptoms (the "menopausal index"). A score of 20 or less indicates a moderate climacteric syndrome, 21-34 points means that its severity is moderate to high, and with more than 35 points the syndrome is severe.

Ethical issues. The study was voluntary and each participant signed a consent form and was assured that the study would be kept anonymous. The purpose of the study and how the questionnaires should be filled- in was explained to the respondents. The study was carried out in compliance with the Declaration of Helsinki and consent to conduct the study granted by the Bioethical Committee of the Medical University in Lublin (No. KE-0254/157/2013).

Statistical analysis. The collected material was subjected to a statistical analysis. The quantitative variables were described with a mean and a standard deviation. For the qualitative variables, the number and percentage of indicated categories were provided. In order to verify the hypotheses, appropriate statistical tests were applied: the chi-square test, the Student's t-test for independent groups and Wilcoxon Mann-Whitney test. The results of the analysis were accepted as statistically significant if $\mathrm{p}<0.05$. The statistical analysis was performed on IBM SPSS Statistics software (version 21).

\section{RESULTS}

Respondents' socio-demographic characteristics, menopause symptoms and chosen health behaviours. The study involved 102 postmenopausal women aged 40-82 (56 \pm 7.8 years). Female residents of rural areas accounted for more than half $(54 ; 52.9 \%)$ of the respondents, whereas urban areas were represented by 48 women $(47.1 \%)$. The majority $(86 ; 84.3 \%)$ of the study group had planned on staying in hospital, as opposed to $16(15.7 \%)$ respondents who had not planned it. The majority of women $(88 ; 86.3 \%)$ reported that their menstruation had ceased for natural reasons, whereas in others $(14 ; 13.7 \%)$ menstruation had stopped following a hysterectomy. Hot flashes were reported by every fifth (58; $20.9 \%$ ) respondent, sleep disorders by 55 , and irritable mood by 43.21 women $(7.6 \%)$ stated that they had depression. The vast majority $(94 ; 92.2 \%)$ of the surveyed women were characterised by moderate severity of climacteric symptoms; 6 (5.9\%) of them experienced medium severity. Two (2.0\%) women admitted that they were not experiencing any such symptoms. Table 1 presents the degrees of severity of the climacteric syndrome depending on the place of residence. No statistically significant differences were observed between the residents of rural and urban areas as regards intensification of the climacteric syndrome ( $\mathrm{p}>0.05)$.

The majority of the women $(89 ; 87.3 \%)$ did not undergo treatment for menopausal symptoms. Only 7 (6.7\%) women were receiving hormone replacement therapies (HRT) and 6
Table 1. Degree of severity of climacteric syndrome vs. place of residence

\begin{tabular}{|c|c|c|c|c|c|c|}
\hline \multirow{3}{*}{$\begin{array}{l}\text { Place of } \\
\text { residence }\end{array}$} & \multicolumn{6}{|c|}{ Kupperman Index } \\
\hline & \multicolumn{2}{|c|}{ No symptoms } & \multicolumn{2}{|c|}{$\begin{array}{l}\text { Moderate: } \\
\text { 21-34 points }\end{array}$} & \multicolumn{2}{|c|}{$\begin{array}{c}\text { Severe: } \\
\text { more than } 35 \text { points }\end{array}$} \\
\hline & $\mathrm{n}$ & $\%$ & $\mathrm{n}$ & $\%$ & $\mathrm{n}$ & $\%$ \\
\hline $\begin{array}{l}\text { Urban area } \\
n=48\end{array}$ & 1 & 2.1 & 2 & 4.2 & 45 & 93.7 \\
\hline $\begin{array}{l}\text { Rural area } \\
n=54\end{array}$ & 1 & 1.9 & 4 & 7.4 & 49 & 90.7 \\
\hline
\end{tabular}

$\mathrm{n}$-frequency; $\%$ - percent

(5.9\%) used plant-based preparations. Half of the respondents $(44 ; 49.4 \%)$ reported that since their physicians had not recommended it, they had never used hormone replacement therapies. $28(31.5 \%)$ respondents refrained from them due to concerns about pharmacotherapies; 6 (6.7\%) respondents did not feel the need for a hormone replacement therapy. There were also $6(6.7 \%)$ women who stated that they did not use an HRT due to medical contraindications.

More than half $(60 ; 58.8 \%)$ of the study group stated that they were sexually active; $42(41.2 \%)$ were not. More than half $(61 ; 59.8 \%)$ of the respondents indicated that they spent their free time actively; the remaining 41 (40.2\%) opted for passive forms of leisure, such as watching TV or reading.

58 (56.9\%) respondents perceived their health as "good", whereas for 34 (33.3\%) it was "fair". 4 (3.9\%) women assessed it to be "very good" and only 6 (5.9\%) as "poor". Compiled data on women's self-assessment of health by place of residence are shown in Table 2 . No statistically significant correlation was found between self-assessment of health and place of residence $(\mathrm{p}>0.05)$.

Table 2. Respondents' self-assessment of health vs. place of residence

\begin{tabular}{lcccc}
\hline \multirow{2}{*}{ Place of residence } & \multicolumn{4}{c}{ Self-assessment of health } \\
\cline { 2 - 5 } & \multicolumn{2}{c}{ Very good/Good } & \multicolumn{2}{c}{ Fair/Poor } \\
\cline { 2 - 5 } & $\mathrm{n}$ & $\%$ & $\mathrm{~N}$ & $\%$ \\
\hline $\begin{array}{l}\text { Urban area } \\
\mathrm{n}=48\end{array}$ & 26 & 54.2 & 22 & 45.8 \\
\hline $\begin{array}{l}\text { Rural area } \\
\mathrm{n}=54\end{array}$ & 35 & 64.8 & 19 & 35.2 \\
\hline Significance & Chi-square $=0.947 ; \mathrm{p}=0.442$ [with Yates' correction] \\
\hline
\end{tabular}

n-frequency; $\%$ - percent

It was analysed whether postmenopausal women undergo preventive health examinations on a regular basis. More than half $(71 ; 69.6 \%)$ of the respondents stated that they regularly participated in such examinations, whereas one in $3(31 ; 30.4 \%)$ admitted that they did not do so. Respondents' answers further showed that $30(29.4 \%)$ women performed cytology once a year and $29(28.4 \%)$ did it less than once a year. The remaining $43(42.2 \%)$ respondents underwent this examination once every 2 years.

The study shows that more than half $(62 ; 60.8 \%)$ of the women occasionally performed breast self-examination, while nearly one in $4(18 ; 17.6 \%)$ did not do it because they did not consider it necessary. Only 11 (10.8\%) respondents declared that they performed self-examination regularly every month, on a specific day of their choice. Only one in 3 (40; $34.5 \%$ ) women stated that they underwent mammography, as opposed to the rest who did not undergo this examination. 
Intensification of health behaviours in postmenopausal women and their evaluation of health. The overall health behaviour indicator (HBI) in the study group was found to reach an average value of $80.1 \pm 12.7$ points. The lowest and highest values of the indicator were 46 points (1 STEN) and 107 points (9 STEN), respectively. Half of the women obtained a value in excess of 79.5 points ( 5 STEN), and every fourth had an indicator of more than 91.3 points (6 STEN).

The point of interest was the respective types of health behaviour in the analysed group (Tab. 3).

Table 3. Overall health behaviour indicator for each category

\begin{tabular}{lcl}
\hline Behaviour category & M & SD \\
\hline Proper eating habits (PEH) & 3.33 & 0.6 \\
\hline Preventive behaviours (PB) & 3.41 & 0.7 \\
\hline Positive mental attitude (PMA) & 3.33 & 0.7 \\
\hline Health practices (HPs) & 3.25 & 0.6 \\
\hline
\end{tabular}

$\mathrm{M}$ - mean; $\pm \mathrm{SD}$ - standard deviation

Preventive behaviours were the prevailing pattern of health behaviour. The mean expressing the health behaviour indicator (HBI-PB) was lower in relation to the standardisation group (which serves as a reference for the interpretation of own research). This was followed by proper eating habits $(\mathrm{PEH})$ and positive mental attitude (PMA), where the mean was lower than in the standardisation group. Finally, health practices (HPs), also with a mean lower than in the comparative group.

The next step was statistical analysis regarding the possible relationship between age and health behaviours. Taking into account the median $(\mathrm{Me}=56)$ of the women's age, the respondents were divided into 2 age groups: under 56 and aged 56 and over. Younger respondents, under 56 years of age, obtained a slightly higher overall HBI indicator and slightly higher results in dimensions of $\mathrm{PEH}$ and $\mathrm{PB}$. Whereas older respondents, aged 56 and over, obtained slightly higher results in the dimensions of PMA and HPs. However, age turned out to be a variable that did not significantly differentiate the health behaviours of the surveyed women (Tab. 4). Lack of statistical differences between health behaviours and age was additionally confirmed by the analysis of linear correlation.

In addition, it was analysed whether the women's health behaviours were differentiated by the age at which they had their last menstruation. The respondents were divided into 2 groups: under 50 and aged 50 and over. Women who reported their last menstruation before the age of 50 obtained slightly higher overall HBI indicator than those who had their last menstruation later - over 50 years of age. However, the results were not statistically significant. Statistically significant difference was observed in dimension of health practices (HPs) ( $\mathrm{p}<0.05)$. Women who reported their last menstruation before the age of 50 obtained higher results in this dimension of health behaviour (Tab. 4).

It was also interesting to discover whether the women who had ceased their menstruation for natural reasons reported different health behaviours than those whose menstruation had stopped following a hysterectomy. Analysis with the Wilcoxon Mann-Whitney test did not show any statistically significant difference between these 2 groups of respondents $(\mathrm{p}>0.05)$. Slightly higher results in all categories of health behaviours were obtained by women whose menstruation stopped for natural reasons (Tab. 4).
Table 4. Value of postmenopausal women's health behaviour indicators depending on their age, age at last menstruation, natural vs. surgical menopause

\begin{tabular}{|c|c|c|c|c|c|}
\hline \multirow{2}{*}{$\begin{array}{l}\text { Age of } \\
\text { women }\end{array}$} & \multicolumn{5}{|c|}{$M \pm S D$} \\
\hline & $\begin{array}{c}\text { Overall indicator } \\
\mathrm{HBI}\end{array}$ & PEH & PB & PMA & HPs \\
\hline $\begin{array}{l}\text { Under } 56 \\
n=47\end{array}$ & $80.74 \pm 11.48$ & $3.40 \pm 0.60$ & $3.47 \pm 0.64$ & $3.29 \pm 0.74$ & $3.23 \pm 0.54$ \\
\hline $\begin{array}{l}56 \text { and over } \\
\mathrm{n}=55\end{array}$ & $79.60 \pm 13.72$ & $3.28 \pm 0.62$ & $3.37 \pm 0.77$ & $3.38 \pm 0.66$ & $3.27 \pm 0.63$ \\
\hline Significance & $\begin{array}{l}t=0.452 \\
p=0.652\end{array}$ & $\begin{array}{l}t=0.976 \\
p=0.331\end{array}$ & $\begin{array}{l}t=0.719 \\
p=0.474\end{array}$ & $\begin{array}{l}t=-0.653 \\
p=0.515\end{array}$ & $\begin{array}{l}t=-0.271 \\
p=0.787\end{array}$ \\
\hline $\begin{array}{l}\text { Age at the } \\
\text { last menstru- } \\
\text { ation }\end{array}$ & $\begin{array}{l}\text { Overall indicator } \\
\qquad \mathrm{HBI}\end{array}$ & PEH & PB & PMA & $\mathrm{HPs}$ \\
\hline $\begin{array}{l}\text { Under } 50 \\
n=49\end{array}$ & $80.73 \pm 14.31$ & $3.33 \pm 0.68$ & $3.43 \pm 0.80$ & $3.33 \pm 0.73$ & $3.54 \pm 0.64$ \\
\hline $\begin{array}{l}51 \text { and over } \\
\mathrm{n}=53\end{array}$ & $79.57 \pm 11.10$ & $3.33 \pm 0.54$ & $3.40 \pm 0.63$ & $3.34 \pm 0.67$ & $3.17 \pm 0.53$ \\
\hline Significance & $\begin{array}{l}t=0.463 \\
p=0.644\end{array}$ & $\begin{array}{l}t=-0.001 \\
p=0.999\end{array}$ & $\begin{array}{l}t=0.162 \\
p=0.872\end{array}$ & $\begin{array}{l}t=-0.042 \\
p=0.967\end{array}$ & $\begin{array}{l}t=2.469 \\
p=0.045\end{array}$ \\
\hline $\begin{array}{l}\text { Natural vs. } \\
\text { surgical } \\
\text { menopause }\end{array}$ & $\begin{array}{l}\text { Overall indicator } \\
\qquad \mathrm{HBI}\end{array}$ & PEH & PB & PMA & $\mathrm{HPs}$ \\
\hline $\begin{array}{l}\text { Natural } \\
\mathrm{n}=88\end{array}$ & $80.24 \pm 12.58$ & $3.34 \pm 0.62$ & $3.42 \pm 0.72$ & $3.34 \pm 0.68$ & $3.26 \pm 0.58$ \\
\hline $\begin{array}{l}\text { Surgical } \\
\mathrm{n}=14\end{array}$ & $79.43 \pm 13.85$ & $3.32 \pm 0.54$ & $3.39 \pm 0.68$ & $3.31 \pm 0.83$ & $3.21 \pm 0.65$ \\
\hline Significan & $\begin{array}{l}z=-0.307 \\
p=0.759\end{array}$ & $\begin{array}{c}z=-0.152 \\
p=0.880\end{array}$ & $\begin{array}{c}z=-0.219 \\
p=0.826\end{array}$ & $\begin{array}{c}z=-0.215 \\
p=0.830\end{array}$ & $\begin{array}{c}z=-0.312 \\
p=0.755\end{array}$ \\
\hline
\end{tabular}

$\mathrm{M}$ - mean; \pm SD - standard deviation; PEH - Proper Eating Habits; PB - Preventive Behaviours; PMA - Positive Mental Attitude; HPs - Health Practices; $t$ t test for independent groups; $z$ Wilcoxon Mann-Whitney test

The authors' point of interest was whether the value of the overall health behaviour indicator of the respondents and the values of indicators for each category of health behaviours depended on their place of residence. A higher $\mathrm{HBI}$ indicator was found to be characteristic of urban rather than rural residents. However, with no statistically significant difference ( $>0.05$ ). Moreover, urban residents obtained higher results in all dimensions of health behaviours, and in PMA the difference was statistically significant $(p=0.028)$ (Tab. 5).

Furthermore, the authors were interested in what value the respondents attributed to health (Tab. 6). The respondents attributed the highest importance to health understood as a property, state and goal. This was followed by health perceived as a result. For women, being healthy primarily

Table 5. Value of postmenopausal women's health behaviour indicators depending on place of residence

\begin{tabular}{lccccc}
\hline \multirow{2}{*}{$\begin{array}{l}\text { Place of } \\
\text { residence }\end{array}$} & \begin{tabular}{c} 
Overall \\
indicator \\
\cline { 2 - 6 }
\end{tabular} & PEI & $P B$ & PMA & HPs \\
\hline $\begin{array}{l}\text { Urban area } \\
n=48\end{array}$ & $82.4 \pm 11.4$ & $3.38 \pm 0.57$ & $3.48 \pm 0.70$ & $3.48 \pm 0.59$ & $3.33 \pm 0.52$ \\
\hline $\begin{array}{l}\text { Rural area } \\
n=54\end{array}$ & $77.6 \pm 13.6$ & $3.27 \pm 0.65$ & $3.32 \pm 0.72$ & $3.17 \pm 0.77$ & $3.16 \pm 0.65$ \\
\hline Significance & $\begin{array}{c}\mathrm{t}=-1.918 \\
\mathrm{p}=0.058\end{array}$ & $\begin{array}{c}\mathrm{t}=-0.868 \\
\mathrm{p}=0.387\end{array}$ & $\begin{array}{c}\mathrm{t}=-1.113 \\
\mathrm{p}=0.269\end{array}$ & $\begin{array}{c}\mathbf{t}=-\mathbf{2 . 2 2 8} \\
\mathbf{p}=\mathbf{0 . 0 2 8}\end{array}$ & $\begin{array}{c}\mathrm{t}=-1.489 \\
\mathrm{p}=0.140\end{array}$ \\
\hline
\end{tabular}

M - mean; \pm SD - standard deviation; PEH - Proper Eating Habits; PB - Preventive Behaviours; PMA - Positive Mental Attitude; HPs - Health Practices; $t$ - $t$ test for independent groups 
Table 6. Mean weights of postmenopausal women's statements on health

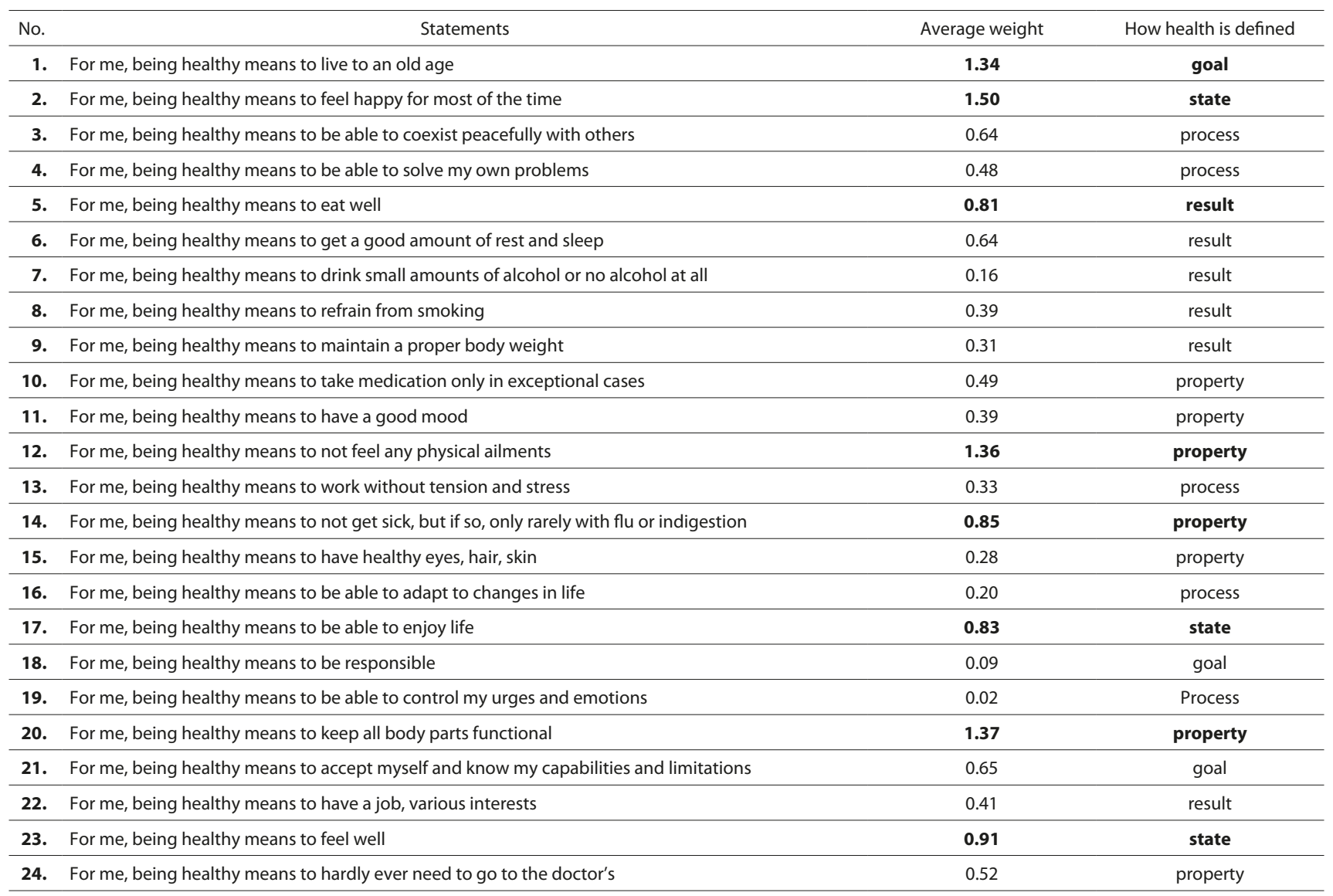

means to "feel happy most of the time", "keep all body parts functional", "not feel any physical ailments", and "live to an old age". Less importance was assigned to the following statements: "be able to control my urges and emotions", "be responsible", "be able to adapt to changes in life", "drink small amounts of alcohol or no alcohol at all", "have healthy eyes, hair and skin".

It was also interesting to discover whether the respondents understood the term "health" differently depending on their age and place of residence. The analysis did not show any statistically significant differences regarding perception of health by women under 56 years of age and over 56 years of age ( $>0.05)$. Regarding place of residence, statistically significant differences were observed in the weight of the statement according to which health is a process of "being able to work without tension and stress", as the respondents from urban areas assigned to it a higher average weight than those from rural areas $(p<0.05)$. Differences with statistical significance were also found in the weight of the statement defining health as a property of the human body: "not get sick and if so, only rarely with flu or indigestion" - women from rural areas assigned to it a higher average weight than those from urban areas $(p=0.05)$. Furthermore, there was a difference approximating statistical significance regarding the statement describing health as being the aim of "being responsible". Women from rural areas awarded this statement a higher score than those from urban areas (Tab. 7).

\section{DISCUSSION}

The notion of health, as stipulated in "The Mandala of Health" concept, is to be understood comprehensively and include the body, the mind and the spirit [12]. Self-assessment of health is an epidemiological research method, increasingly used to evaluate the health of the population [20]. In own research, the subjective assessment of one's own health turned out to be average, as more than half (56.9\%) of women rated it as good and one in $3(33.3 \%)$ as fair. It should be stressed that the majority of women living in rural areas were those who assessed their own health as very good and good (64.8\%). The findings in this scope in the current study are different from results of a survey among 959 Chinese women aged 50 or above, in which the majority perceived their health status as "fair" or "poor" (62\%) [21].

Women expressed concern about their health by, among other things, participating in preventive examinations. The results showed that more than half $(69.6 \%)$ of the respondents used preventive examinations, while one in $3(30.4 \%)$ stated they did not. Cytology was most preferred by women after menopause, with $29.4 \%$ and $42.2 \%$ of the respondents performing it once or twice a year, respectively. At the same time, every third (34.5\%) woman reported also undergoing mammography. Breast self-examination was performed every month by $10.8 \%$ and occasionally by $60.8 \%$ of the respondents; $28.4 \%$ of them did not examine their breasts. The study by Słopiecka [22] conducted among 210 women aged 18-73 showed that more than half (59.0\%) of them underwent preventive examinations of the reproductive 
Table 7. Mean weights of postmenopausal women's statements on health in relation to place of residence

\begin{tabular}{|c|c|c|c|c|c|c|c|c|c|}
\hline \multirow[b]{2}{*}{ No. "For me, being healthy means to..." } & \multicolumn{2}{|c|}{ Average weight } & \multicolumn{2}{|c|}{ Significance } & \multicolumn{2}{|c|}{ Average weight } & \multicolumn{2}{|c|}{ Significance } & \multirow{2}{*}{$\begin{array}{l}\text { How } \\
\text { health is } \\
\text { defined }\end{array}$} \\
\hline & $\begin{array}{c}\text { Age } \\
\text { under } 56\end{array}$ & $\begin{array}{l}\text { Age } 56 \\
\text { and over }\end{array}$ & $\mathrm{t}$ & $\mathrm{p}$ & rural area & $\begin{array}{l}\text { urban } \\
\text { area }\end{array}$ & $\mathrm{t}$ & $\mathrm{p}$ & \\
\hline 1. live to an old age & 1.20 & 1.45 & -0.669 & 0.505 & 1.19 & 1.46 & -0.703 & 0.484 & goal \\
\hline 2. feel happy most of the time & 1.52 & 1.49 & 0.071 & 0.943 & 1.32 & 1.67 & -0.810 & 0.420 & state \\
\hline 3. be able to coexist peacefully with others & 0.71 & 0.58 & 0.414 & 0.680 & 0.61 & 0.67 & -0.186 & 0.853 & process \\
\hline 4. be able to solve my own problems & 0.41 & 0.53 & -0.479 & 0.633 & 0.47 & 0.48 & -0.056 & 0.955 & process \\
\hline 5. eat well & 0.93 & 0.71 & 0.722 & 0.472 & 0.91 & 0.72 & 0.617 & 0.539 & result \\
\hline 6. get a good amount of rest and sleep & 0.59 & 0.69 & -0.403 & 0.688 & 0.53 & 0.74 & -0.813 & 0.418 & result \\
\hline 7. drink small amounts of alcohol or no alcohol at all & 0.15 & 0.16 & -0.083 & 0.934 & 0.28 & 0.06 & 1.531 & 0.132 & result \\
\hline 8. refrain from smoking & 0.41 & 0.36 & 0.214 & 0.831 & 0.55 & 0.24 & 1.339 & 0.184 & result \\
\hline 10. take medication only in exceptional cases & 0.43 & 0.53 & -0.406 & 0.686 & 0.60 & 0.39 & 0.911 & 0.364 & property \\
\hline 11. have a good mood & 0.43 & 0.35 & 0.417 & 0.678 & 0.23 & 0.52 & -1.368 & 0.174 & property \\
\hline 12. not feel any physical ailments & 1.39 & 1.33 & 0.171 & 0.864 & 1.55 & 1.19 & 0.990 & 0.325 & property \\
\hline 13. be able to work without tension and stress & 0.28 & 0.36 & -0.396 & 0.693 & 0.11 & 0.52 & -2.162 & 0.034 & process \\
\hline 14. not get sick, and if so, only rarely with flu or indigestion & 0.80 & 0.89 & -0.292 & 0.771 & 1.17 & 0.57 & 2.006 & 0.048 & property \\
\hline 15. have healthy eyes, hair, skin & 0.26 & 0.29 & -0.169 & 0.866 & 0.34 & 0.22 & 0.668 & 0.506 & property \\
\hline 16. be able to adapt to changes in life & 0.24 & 0.16 & 0.555 & 0.580 & 0.15 & 0.24 & -0.676 & 0.500 & process \\
\hline 17. be able to enjoy life & 0.78 & 0.87 & -0.321 & 0.749 & 0.85 & 0.81 & 0.129 & 0.898 & state \\
\hline 18. be responsible & 0.11 & 0.07 & 0.380 & 0.704 & 0.19 & 0.00 & 1.930 & 0.060 & goal \\
\hline 19. be able to control my urges and emotions & 0.02 & 0.02 & 0.127 & 0.900 & 0.02 & 0.02 & 0.098 & 0.922 & process \\
\hline 20. keep all body parts functional & 1.30 & 1.42 & -0.308 & 0.759 & 1.49 & 1.26 & 0.624 & 0.534 & property \\
\hline 23. feel well & 0.83 & 0.98 & -0.476 & 0.635 & 0.94 & 0.89 & 0.145 & 0.885 & state \\
\hline 24. hardly ever need to go to the doctor's & 0.37 & 0.65 & -1.446 & 0.151 & 0.45 & 0.59 & -0.718 & 0.475 & property \\
\hline
\end{tabular}

$\mathrm{t}-\mathrm{t}$ test for independent groups

organs less than once every 2 years, or did not participate in them at all. The remaining group (41.0\%) reported regular participation, i.e. at least once every 2 years.

It follows from the analysis of the results cited above that only $36 \%$ of the respondents regularly, i.e. once a year or every 2 years, performed a cytology, and that one in 3 women were unable to recall how often they had undergone this examination. Surprisingly, $16 \%$ of the women reported to have never undergone a cytological examination. A report by Woźniak [23] from a study involving 100 female patients aged 18-74 (with the largest group aged 41-50) revealed that only $28 \%$ of them performed breast self-examination once a month; "once a year" was the frequency reported by every fifth (22\%) woman. A matter of concern is that almost every second (48\%) respondent in the cited study admitted to not examining her breasts at all. The said report also showed that one in 3 (29\%) women performed cytological and gynaecological examinations once a year, and for nearly one in $4(23 \%)$ this was once every 2 years. There were also women who admitted to never having undergone cytological checkups or gynaecological examinations ( $9 \%$ and $5 \%$, respectively). A study by Skórzyńska et al. [24] among 150 women over 50 years of age revealed that they did not perform cytology or mammography more regularly $(61.3 \%$ of the surveyed women had undergone cytology and $51.3 \%$ mammography in the last 2 years), and medical recommendations regarding early detection of cancers were frequently ignored by them. The results from the study among Chinese women at the same age were even worse: half of surveyed women (52.1\%) had never had a cytology, and $66 \%$ of them thought that this test was not necessary after menopause [21].

The overall HBI of women surveyed was average $(\mathrm{M}=80.1 \pm 12.7)$, which corresponds with Juczyński’s standardisation results $(M=85.98 \pm 12.70)$ [18]. However, the mean characterising the indicator in this study was lower than in the case of the authors' questionnaire. The author noted that postmenopausal women engaged in more health-promoting behaviours, compared to younger people. An exception to this (in favour of the younger population), in his opinion, may be those affected by certain chronic diseases [18]. In recent years, older-age groups have been observed to exhibit a fairly stable trend of improving their health behaviours. Some authors have even reported above-average results obtained by the older population [25]. This differs from the findings of Kurowska and Kierzenkowska [26] who discovered that women aged over 60 obtained poorer results overall in this area. In the current study, the age of surveyed women did not significantly influence their health behaviours.

The presented results show that preventive behaviours (PB) exhibited the strongest manifestation in postmenopausal 
women $(M=3.41 \pm 0.70)$. In this category, respondents were asked about issues such as avoiding cold, following doctors' recommendations, knowing emergency telephone numbers, and being interested in health prevention and information on how to maintain good health. These were followed by issues related to proper eating habits $(\mathrm{PEH})(\mathrm{M}=3.33 \pm 0.6)$ and positive mental attitude (PMA) $(\mathrm{M}=3.33 \pm 0.6)$. The above factors, however, were observed to exhibit fairly low psychometric properties when compared to the results presented in the study by Juczyński [18].

In the first category (PEH), the assessment covered the consumption of fruit and vegetables, restricting the intake of animal fats, sugar, salt and highly salted foods, as well as the frequency of consumption of wholemeal bread. Reports in the literature indicate the importance of following the principles of healthy nutrition to aid the prevention of postmenopausal diseases (metabolic syndrome, ischaemic heart disease, diabetes, malignant tumours, osteoporosis and depressive disorders) $[27,28,29]$. Detailed eating habits in this group of women were not analysed. However, some of the literature on the subject suggests that the diet of postmenopausal women is still unsatisfactory. Irregularities in this respect generally stem from excessive daily caloric intake, incorrect fat ratios (saturated vs. unsaturated fats), and mineral and vitamin deficiencies [30]. It is therefore worthwhile for these issues to be addressed in other studies in the future.

With regard to the PMA, issues such as the avoidance of depressing situations, extreme emotion and tension, as well as those related to social life, were taken into account. The fairly low psychometric properties of this factor may be considered unfavourable for the mental health of postmenopausal women. This is because the incidence of various mental disorders, especially depression and anxiety disorders, tends to increase in this age group $[31,32,33,34,35]$. Compared to younger populations, these women tend to experience more negative emotions, such as anxiety, sadness and exhaustion [36]. Therefore, avoiding stressors in everyday life can directly contribute to their ability to restore and maintain emotional balance $[37,38]$.

The last position was taken by health practices (HPs) $(M=3.25 \pm 0.75)$, the impact of which in the analysed group was lower than in Juczyński's study [18]. These included times devoted to rest, avoidance of overwork and excessive physical effort, weight control, and refraining from smoking. Various health activities are included in this category, with most attention being paid to physical recreation.

It is satisfying to note that more than half of the women (59.8\%) reported engaging in physical exercise during their free time. Similar results were obtained by other authors where this proportion reached $48 \%$; only $1.8 \%$ of the respondents admitted undertaking intensive and regular forms of physical activity [39]. In the study by Marlatt et al [40] among 1,611 peri- and post-menopausal women, those who reported lower exercise frequency (i.e. "rarely" or "occasionally") had a higher modified Kupperman Index score, compared to women who reported higher exercise frequency (i.e. "at least 3 times per week" or "almost daily") ( $\mathrm{p}<0.0001)$. It should be stressed that a low level of physical activity in this period of life may be associated with the occurrence of specific health problems [41]. Some authors also point out that the athletes' community is dominated by young women; older women may therefore feel anxious about being judged for attractiveness and fitness [42]. Moreover, inconveniences caused by climacteric symptoms discourage them from undertaking physical activity [36]. It should be noted that some research reveals that regular physical activity undertaken by post-menopausal women can have an antidepressant effect, which is very important in this period of life. In a randomised controlled trial amongst 121 post-menopausal and inactive women without depressive disorders, a moderate-intensity, 6-month walking intervention comprised of 3 sessions of 40 minutes per week, decreased the Beck Depression Inventory score levels [32].

With "place of residence" assumed as a differentiating variable, it is unsatisfactory to note that the overall health behaviour indicator (HBI) was lower in women from rural areas, compared to those living in urban areas. Its value oscillated between low and average $(77.6+13.6$, i.e. between STENEs 4 and 5), which may indicate slightly less concern for one's health in this group of women, even though in self-assessment of health their results were higher than of urban residents.

It should be stressed that Juczyński [18] as well as other authors [6] offered a completely different distribution of results in relation to the overall health behaviour indicator and for all categories of behaviour in postmenopausal women. An undeniable fact, however, is that both the results presented by these and other authors serve to show that women do not take sufficient care of their own health. The average results in terms of health-related behaviours undertaken by women cannot be considered satisfactory as they are more susceptible to various psychophysical disorders during this period [43]. The obtained results suggest the need for healthpromoting and preventive programmes addressed to women in perimenopause. It is important for women to be aware that the quality of their life in the fifth and subsequent decades depends on how much care of health they take. This is also highlighted in other studies [21, 40,44].

It is also important to know what the term "being healthy" means for women past menopause. It was observed that the respondents understood health primarily as a state of the body ("to feel happy for most of the time") and a life goal ("to live to old age"). In addition, they perceived health as a property ("to not feel any physical ailments", "to keep all parts of the body functional"). In a study by other authors conducted in a cohort of senior citizens, health was found to be understood mainly as a property $[45,46]$. Similarly, in the study by Deluga et al., health perceived as a property achieved the highest scores also among younger respondents, i.e. those aged 40 and over [47].

The studies by Nowicki et al. [10] with 150 participants aged from 22 to 62 ( 40.7 years being the average age) demonstrated that the respondents attached primary importance to health seen as a state, result and property, and only then as a goal. In the respondents' view, being healthy primarily meant to "keep all body parts functional", "not feel any physical ailments", "feel happy most of the time", "eat well", and "not get sick, and if so, only rarely with flu or indigestion". Much less important for them were the statements "hardly ever need to go to the doctor's", "be able to enjoy life", "feel well", and "maintain a proper body weight". According to the respondents, analysis of the most important statements on health revealed statistically significant correlations in the assumption "to keep all parts of the body functional", which was considered more important by males. No statistically significant differences were found with regard to the other statements. 
In the study by Słopiecka [22], the respondents reported understanding the term "health" as complete physical, mental and social well-being. For women aged $\geq 56$ years, health was "the absence of disease". Own research suggests that health tends to be defined differently depending on the place of residence. A correlation was found between the respondent's place of residence and his or her definition of health. Women living in rural areas were more likely to perceive health instrumentally, expressing statements in which health acted as a property of the body (not fall ill, and if so, only rarely with flu or indigestion, and/or take medication only in exceptional cases; keep all parts of the body functional) and/or as a goal (be responsible). Those from urban areas, in turn, tended to rate higher their statements describing health as a process (work without tension and stress).

Study limitations. This study has some limitations. The first is the sampling method. A small group of women from only one hospital were invited to participate in the study, which made it impossible to generalize the results. Additionally, no previous health history of the women was studied, nor their previous health behaviours, which made impossible comparisons and analyses of changes occurring in this regard. Therefore, further research is recommended in a larger group and with more data collected concerning the health condition of the women past menopause and its impact on health behaviours. Another important limitation is the age of the women surveyed. The main inclusion criteria for women to take part in the study was past menopause, and this state occurs sometimes at an early age. As a result of this, the study group comprised women from different age decades, from 40-82. Despite the lack of statistical differences between the age of the women and their health behaviours and health perception, further research is recommended in a larger group to investigate the relationship between these variables.

\section{CONCLUSIONS}

1. A higher overall HBI, as well as indicators for particular categories, were characteristic of women from urban areas. Especially the results in the dimension of positive mental attitude were higher for urban residents, and this difference was statistically significant. Rural residents were dominant in the group of women who rated their health to be very good or good.

2. The age of surveyed women did not significantly influence their health behaviours. However, women who reported their last menstruation before the age of 50, obtained higher results in health practices.

3. The respondents attributed the highest importance to health understood as a property, state and goal. Compared to the urban respondents, those from rural areas attributed a higher value of average weight to the statements "not fall ill, and if so, only rarely with flu or indigestion" (property) and "be responsible" (goal). A higher average value was assigned by the urban respondents to the statement "be able to work without tension and stress" (process). There was no statistically significant difference between the women's age and their perception of health.

\section{REFERENCES}

1. Yazdkhasti M, Simbar M, Abdi F. Empowerment and coping strategies in menopause women: a review. Iran Red Crescent Med J. 2015; 17(3): e18944. doi: 10.5812/ircmj.18944.

2. Yanikkerem E, Göker A, Çakır Ö, Esmeray N. Effects of physical and depressive symptoms on the sexual life of Turkish women in the climacteric period. Climacteric. 2018; 21(2): 160-166.

3. Gruszczyńska M, Bąk-Sosnowska M, Plinta R. Zachowania zdrowotne jako istotny element aktywności życiowej człowieka. Stosunek Polaków do własnego zdrowia [Health-related behaviors as an essential part of human life activities. Attitude of Poles towards their own health]. Hyg Pub Health. 2015; 50(4): 558-565. [in Polish]

4. Jaspers L, Daan NM, Van Dijk GM, Gazibara T, Muka T, Wen KX, Meun C, Zillikens C, Roeters van Lennep JE, Roos-Hesselink JW, Laan E, Rees M, Laven JSE, Franco OH, Kavousi M. Health in middle-aged and elderly women: a conceptual framework for healthy menopause. Maturitas. 2015; 81(1): 93-98.

5. Sehhatie F, MojganM, Kafiyeh M. Health promoting behaviors among postmenopausal women in Langroud city, Iran. IJWHR. 2015; 3(3): $158-162$.

6. Weber-Rajek M, Lubomska M, Radzimińska A, LulińskaKuklik E, GochA, Zukow W. Zachowaniazdrowotnekobiet w okresiemenopauzalnym [The health behavior of women during menopausal period]. J Educ Health Sport. 2016; 6(2): 151-162. [in Polish]

7. Ferrer RA, Klein WMP. Risk perceptions and health behavior. Curr Opin Psychol. 2015; 5: 85-89.

8. Ogińska-Bulik N, Zadworna-Cieślak M, Rogala E. Rola zasobów osobistych w podejmowaniu zachowań zdrowotnych przez osoby w wieku senioralnym [Role of personal resources in prediction of health behaviors in seniors]. Probl Hig Epidemiol. 2015; 96(3): 570-577. [in Polish]

9. Jopkiewicz A. Samoocena zdrowia, jakości życia i zaradności życiowej osób starszych [Self-evaluation of health, quality of life and resourcefulness of life in elderly people]. Rocznik Lubuski. 2014; 4(2): 261-273. [in Polish]

10. Nowicki G, Młynarska M, Ślusarska B, Rudnicka-Drożdżak E, SzczekalaK, Bartoszek A. The relationship between the value of health and health behaviors in individuals over 65 years of age. Fam Med Primary Care Rev. 2017; 1: 49-53.

11. Piasecka H, ŚlusarskaB, Nowicki G. Zdrowie jako wartość wśród młodzieżystudenckiejw uwarunkowaniach społeczno-demograficznych i ocena żywienia badanej grupy [The value of health in the perception of students in terms of socio-demographic determinants and the evaluation of eating habits of the surveyed]. Pielęg Pol. 2015; 56 (2): 127-134. [in Polish]

12. Ślusarska B, Dobrowolska B, Zarzycka D. Metateoretyczny kontekst zachowań zdrowotnych w paradygmatach zdrowia [Metatheoretical context of health behavior in health paradigms]. Probl Hig Epidemiol. 2013; 94(4): 667-674. [in Polish]

13. Horbowska J. Wartość „zdrowie” i jej miejsce w hierarchii wartości młodzieży i osób dorosłych [The value „health" and it's place in the hierarchy of values among youths and adults]. Rocz Pedag. 2017; 9 (45): DOI: http://dx.doi.org/10.18290/rped.2017.9.2-10. [in Polish]

14. Borowiec A, Lignowska I. Czy ideologia healthismu jest cechą dystynktywną klasy średniej w Polsce? [Is the ideology of healthism a distinctive feature of the middle class in Poland?]. KultiSpol. 2012; 56(3): 95-111. [in Polish]

15. Korwin-Szymanowska A. Kiedy otoczenie ma znaczenie: świadomość zdrowotna i wzorce w otoczeniu społecznym jako determinant poziomu aktywności fizycznej studentów [When people around you matter: health awareness and social patterns as determinants of the level of physical activity of students]. Forum Pedag. 2017; 2: 33-47. [in Polish]

16. Lizak D, Seń M, Kochman M. Healthism - afirmacja promocji zdrowia czy współczesne zagrożenie behawioralne? [Healthism - an affirmation of health promotion whether contemporary behavioral threat? In: Żarów $\mathrm{R}$, editor. A man in health and illness. Health promotion. Treatment and rehabilitation. Publisher of the Institute of Health Care, Tarnów2014, p. 148-157. [in Polish]

17. Słopiecka A, Cieślik A. Zachowania zdrowotne - wybrane definicje [Health behavior-selected definitions]. Stud Med. 2011; 24 (4): 77-81. [in Polish]

18. Juczyński Z. Narzędzia pomiaru w promocji i psychologii zdrowia [Tools for health promotion and psychology of health]. $2^{\text {nd }}$ edition. Laboratory of Psychological Tests, Warsaw 2009, p. 106-133.

19. Kupperman HS, Wetchler BB, Blatt MMG. Contemporary therapy of the menopausal syndrome. JAMA 1959; (171): 1627-1637. 
20. Dziankowska-Zaborszczyk E, Ciabiada B, Maniecka-Bryła I. Samoocena stanu zdrowia jako predyktor umieralności przedwczesnej [Self-rated health as a premature mortality predictor]. Probl Hig Epidemiol. 2014; 95(4): 866-870. [in Polish]

21. Chan CWH, Chow Choi K, Wong RS, Ming Chow K, So WKW, Leung DYP, Lam WWT, Goggins W. Examining the cervical screening behaviour of women aged 50 or above and its predicting factors: a population-based survey. Int J Environ Res Public Health. 2016; 13: 1195; doi:10.3390/ijerph13121195

22. Słopiecka A. Analiza wiedzy i zachowań zdrowotnych hospitalizowanych z powodu chorób ginekologicznych oraz kierunki profilaktyki i promocji zdrowia [Analysis of health-related knowledge and behaviours of women hospitalised for gynaecological diseases and future directions of prophylaxis and health promotion]. Stud Med. 2009; (13): 27-35. [in Polish]

23. Woźniak I. Wiedza o schorzeniach nowotworowych narządów kobiecych i postawy kobiet wobec badań profilaktycznych [Knowledge about female genital organs and breast neoplasm and their attitude toward prophylactic tests]. Probl Pielęg. 2008; 16(1,2): 136-143. [in Polish]

24. Skórzyńska H, Krawczyk-Suszek M, Kulik TB, Pacian A, Stefanowicz A, Skowronek A. Attitudes of women after the age of 50 towards preventive screening. Ann Agr Env Med. 2017; 24(4): 624-627.

25. Zadworna-Cieślak M, Ogińska-Bulik N. Zachowania zdrowotne osób $\mathrm{w}$ wieku senioralnym - rola optymizmu [Health behaviors in the group of people in late adulthood period-the role of optimism]. Psychogeriatr Pol. 2013; 10(4): 145-156. [in Polish]

26. Kurowska K, Kierzenkowska E. Poczucie koherencji a zachowania zdrowotne wśród kobiet w okresie menopauzalnym [Sense of coherence in relation to health behaviors among women in menopausal period]. Curr Gynecol Oncol. 2014; 12(3): 206-215. [in Polish]

27. Alkhatib A, Klonizakis M. Effects of exercise training and Mediterranean diet on vascular risk reduction in post-menopausal women. Clin Hemorheol Microcirc. 2014; 57(1): 33-47.

28. Hernández-Angeles C, Castelo-Branco C. Cardiovascular risk in climacteric women: focus on diet. Climacteric. 2016; 19(3): 215-221.

29. Kucharska E. Poprawa zdrowia poprzez prawidłowe żywienie i aktywność fizyczną [Improving health through proper nutrition and physical activity]. In: Podgórska M, editor. Diseases of the 21st century - challenges in the work of a physiotherapist. Publisher of the High School of Management, Gdańsk 2017, p. 258-272. [in Polish]

30. Bojar I, Wierzbińska-Stępniak A, Witczak M, Raczkiewicz D, Owoc A. Are cognitive functions in post-menopausal women related with the contents of macro- and micro-components in the diet? Ann Agric Environ Med. 2015; 22(1): 178-184.

31. Anniverno R, Gadler E, Poli R, Bellomo A, Ventriglio A, Pacilli A M, Barbieri S, Salemi O, Bondi E, Farina A, Mencacci C. Depressive syndrome in perimenopausal and postmenopausal patients. An Italian multicentre observational study. J Psychopathol. 2017; 23: 19-25.

32. Bernard P, Ninot G, Bernard PL, Picot MC, Jaussent A, TallonG, Blain $\mathrm{H}$. Effects of a six-month walking intervention on depression in inactive post-menopausal women: a randomized controlled trial. Aging Ment Health. 2015; 19(6): 485-492. http://dx.doi.org/10.1080/13607863.20 14.948806 .

33. Maki PM, Kornstein SG, Joffe H, Bromberger JT, Freeman EW, Athappilly G, Bobo WV, Rubin LH, Koleva HK, Cohen LS, Soares $\mathrm{CN}$. Guidelines for the evaluation and treatment of perimenopausal depression: summary and recommendations. J Womens Health. 2018; Online Ahead of Print: DOI: 10.1089/jwh.2018.27099.

34. Ostrowska A. Kobiety 50+ w Polsce. Między wyzwaniami społecznymi a możliwościami zdrowotnymi [Women 50 plus in Poland. Between social challenges and health options]. Ann Univ Paedagog Crac. Stud Sociol. 2015; 7(1): 97-114. [in Polish]

35. Tereszko A, Dudek D. Różnicemiędzypłciowe w zaburzeniach psychicznych [Gender differences in mental disorders]. Neuropsychiatr Neuropsychol. 2017; 13(4): 162-169. [in Polish].

36. Bień A, Rzońca E, Pańczyk-Szeptuch M. Życie i funkcjonowanie kobiet w okresie przekwitania [Women's lives and activities during the climacteric period]. Gerontol Pol. 2017; 25(1): 12-19. [in Polish].

37. Wieder-Huszla S, Szkup M, Jurczak A, Samochowiec A, Samochowiec J, Stanisławska M, Rotter I, Karakiewicz B, Grochans E. Effects of socio-demographic, personality and medical factors on quality of life of postmenopausal women. Int J Environ Res Public Health. 2014; 11(7): 6692-6708

38. Wieder-Huszla S, Grześkowiak H, Jurczak A, Pilch D, Stanisławska M, Szkup-Jabłońska M, AugustyniukK, Grochans E. Style radzenia sobie ze stresem kobiet w okresie okołomenopauzalnym z uwzględnieniem intensywności objawów wypadowych [Coping with stress of perimenopausal women in relation to the intensity of climacteric symptoms]. Probl Pielęg. 2014; 22(1): 82-90. [in Polish]

39. Piskorz A, Brzostek T, Piórecka B. Występowanie wybranych czynników ryzyka chorób układu krążenia w grupie kobiet w okresie przed- i pomenopauzalnym - analiza porównawcza [Occurrence of selected cardiovascular risk factors among pre- and postmenopausal women - a comparative study]. Hyg Pub Health. 2015; 50 (1): 127-135. [in Polish]

40. Marlatt KL, Beyl RA, Redman LM. A qualitative assessment of health behaviours and experiences during menopause: a cross-sectional, observational study. Maturitas 2018; 116: 36-42.

41. Ćwirlej-Sozańska A. Ocena wpływu systematycznej aktywności fizycznej na sprawność fizyczną oraz gęstość kości u kobiet w wieku 50-60 lat [Assessment of influence of a regular physical activity on physical condition and bone density in women aged 50-60]. Prz Med Uniw Rzesz Inst Leków. 2015; 2: 116-127. [in Polish]

42. Mandal E, Sitko-Dominik M. Płeć psychologiczna, sprawczość i wspólnotowość, aktywność sportowa oraz taktyki wywierania wpływu w bliskich związkach kobiet w środkowym okresie dorosłości [Gender, agency and communion, physical activity and tactics of influence in close relationships among middle-aged women]. Pol Forum Psycholog. 2017; 22(2): 258-274. [in Polish]

43. Goyal A, Mishra N, Dwivedi S. Nutritional status and health seeking behaviour of postmenopausal women: a cross sectional study in North India. Int J Community Med Pub Health. 2017; 4(12): 4644-4649.

44. Ensan A, Babazadeh R, Aghamohammadian H, Afzal Aghaei M. Effect of training based on choice theory onhealth-promoting lifestyle behaviors among menopausal women. Journal of Midwifery and Reproductive Health. 2018; 6(2): 1253-1263. DOI: 10.22038/jmrh.2018.10469

45. Janiszewska M, Kulik TB, Żołnierczuk-Kieliszek D, PawlikowskaŁagód K, Kryk A. Wartościowanie zdrowia wśród osób starszych na przykładzie studentów Uniwersytetu Trzeciego Wieku [Valuing health among the elderly on the example of students at the university of the third age]. Pielęg Pol. 2016; 1(59): 49-55. [in Polish]

46. Młynarska M, Rudnicka-Drożak E, Nowicki G, Misztal-Okońska P, DyndurJ, Majcher P. Pojęcie zdrowia w opinii osób powyżej 65 roku życia [The concept of health in the opinion of people over 65 years of age]. Gerontol Pol. 2015; 1: 11-18. [in Polish]

47. Deluga A, Dobrowolska B, Kosicka B, Brzozowska A. Wartościowanie zdrowia $\mathrm{w}$ opinii pielęgniarek $\mathrm{w}$ odniesieniu do zmiennych społeczno-demograficznych [Health evaluation with relation to sociodemographic variables - nurses' opinions]. J Educ Health Sport. 2016; 6(4): 167-180. [in Polish] 